\title{
Career Self-efficacy (CSE) Influence towards Selection of Self-employment Career among Riau University Students'
}

Mhd Subhan, Salleh Amat, Abu Yazid Abu Bakar, Mohd Izwan Mahmud, Mas'ud Zein, Heldanit

To Link this Article: http://dx.doi.org/10.6007/IJARBSS/v11-i4/9677

DOI:10.6007/IJARBSS/v11-i4/9677

Received: 05 February 2021, Revised: 07 March 2021, Accepted: 30 March 2021

Published Online: 16 April 2021

In-Text Citation: (Subhan et al., 2021)

To Cite this Article: Subhan, M., Amat, S., Bakar, A. Y. A., Mahmud, M. I., Zein, M., \& Heldanit. (2021). Career Self-efficacy (CSE) Influence towards Selection of Self-employment Career among Riau University Students'. International Journal of Academic Research in Business and Social Sciences, 11(4), 303-314.

Copyright: (c) 2021 The Author(s)

Published by Human Resource Management Academic Research Society (www.hrmars.com)

This article is published under the Creative Commons Attribution (CC BY 4.0) license. Anyone may reproduce, distribute, translate and create derivative works of this article (for both commercial and non-commercial purposes), subject to full attribution to the original publication and authors. The full terms of this license may be seen at: http://creativecommons.org/licences/by/4.0/legalcode

Vol. 11, No. 4, 2021, Pg. 303 - 314

Full Terms \& Conditions of access and use can be found at http://hrmars.com/index.php/pages/detail/publication-ethics 


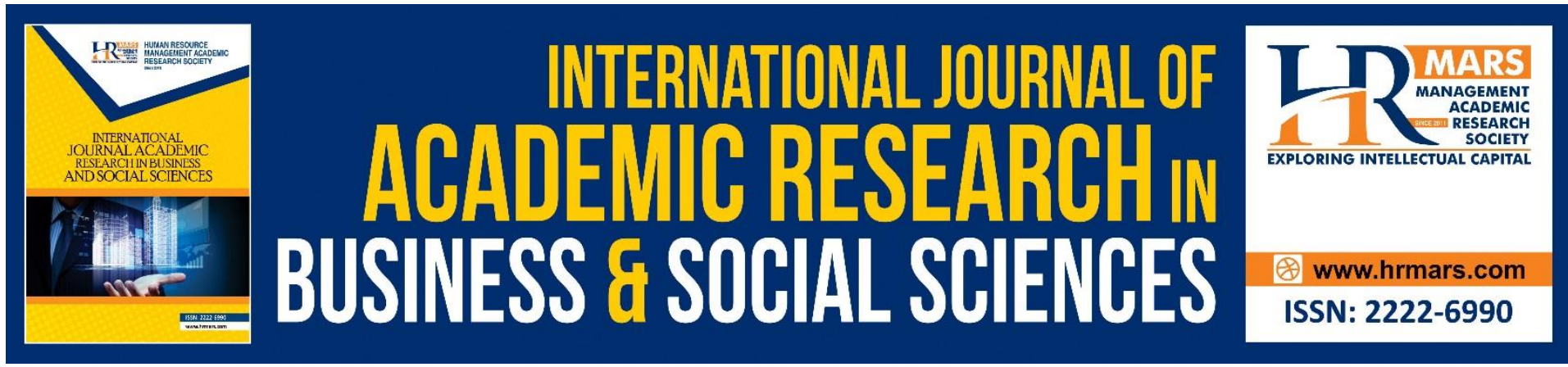

\title{
Career Self-efficacy (CSE) Influence towards Selection of Self-employment Career among Riau University Students'
}

\author{
Mhd Subhan ${ }^{1,2}$, Salleh Amat ${ }^{1}$, Abu Yazid Abu Bakar ${ }^{1}$, Mohd \\ Izwan Mahmud', Mas'ud Zein², Heldanita ${ }^{2}$ \\ ${ }^{1}$ Faculty of Education, Universiti Kebangsaan Malaysia, Bangi, Selangor, Malaysia, ${ }^{2}$ State \\ Islamic University of Sultan Syarif Kasim, Pekanbaru, Riau, Indonesia \\ Email: yazid3338@ukm.edu.my
}

\begin{abstract}
Career Self-Efficacy (CSE) is a person's ability that shows an effort to achieve what he wants for his career goals in decision making. A person's career choice is formed during the exploration stage that explores his desires in that phase. Student's interest to selfemployment creates the ability of being creative and innovative. It also makes them become observant of opportunities and is always open to any input and changes that occur during college and after college. The population of the study consisted of state university students in Riau Province. The sample consisted of 778 students that used random sampling technique. The instrument used is the career decision self-efficacy scale, which has a Cronbach Alpha value of .90 and a self-employment intention instrument that has a Cronbach alpha value of .83. The analysis of this research uses Simple Linear Regression Analysis which is analyzed using the SPSS Version 24 application. The results of this study indicate that student career self-efficacy is at a high stage and the selection of self-employment careers is at a high stage as well. In addition, the researcher found that there is an effect of career self-efficacy on selfemployment career choices among students at the State University of Riau Province, Indonesia. It was found that the $R$ test result was $[r=.414, p<.05]$ which means that is about $41.40 \%$ which was found to be influenced by the two variables. Therefore, the implication of this study shows that the higher the student's career self-efficacy, the higher the career to choose a self-employment career.
\end{abstract}

Keywords: Career Self-Efficacy (CSE), Career Selection, Self-Employment Career, University Students, Indonesia

\section{Introduction}

Entering the era of globalization and the rapid development of technology has contributed to career choices among university students. Those who had graduated from university should be superior, creative, innovative, have strong motivation for achievement, skills, have broad and deep insight into the mastery of knowledge obtained which is expected to be able to bring change in the world of work especially on self-employment. However, in reality, there are many of graduates who choose to work not in accordance with their education field. The 
reality is that the very high unemployment rate among university graduates is increasingly concerning and the existing job opportunities are very limited, apparently still unable to change their perspective. It cannot be denied that most the graduates are still oriented as job seekers rather than job creators. By choosing a self-employment career, someone can channel their creative ideas, skills or talents. Moreover, self-employment can be an alternative solution in overcoming the problem of unemployment in the group of college graduates (Marie, 2021; Abdelkarim, 2021; Saks, 2006).

According to the Central Statistics Agency (2019), unemployment and poverty are currently big problems in Indonesia that have not been resolved as a whole. Statistical reports show 7.05 million of the 267 million people who are found to be heavily unemployed among university graduate students. The factors that cause unemployment in Indonesia include: first, the number of job seekers is greater than the number of job opportunities currently available. Second, there is a gap in the skills possessed by the labor market. Third, there are still many children who drop out of school and the graduates who do not continue their education to the standard level of education of the world of work. Fourth, the willingness and effort to work is still low, and the fifth factor is the immaturity of knowledge and understanding.

The problem of job opportunities nowadays has a minimum acceptance standard for graduates from universities, thus university graduates must have the competence and quality that is able to produce something positive and is expected to solve problems in the world of work. After graduating from university, it is hoped that they will not depend on existing jobs but can create their own jobs by becoming a self-employed. By doing this, the number of unemployed in this country can be decreased (Matijas \& Sersic, 2021; Tiwari, Patro \& Patky, 2020).

In addition, the gap of the graduates in the world of work should not be allowed to drag on which will have a negative impact on future generations. Every year, the college donates educated graduates which results in a lot of unemployment. To create a younger generation that increases job opportunities, high career self-efficacy is needed so that it is easy for individuals to make business plans during college. Several studies have shown self-efficacy as a strong predictor of career choices for secondary and college students (Mahmud et al., 2019; Pambudi, Mulawarman \& Japar, 2018).

A research conducted by Griffin (2020) on western students has successfully revealed that one of the factors associated with career choice is self-efficacy. In an effort to choose a career, students at the university need to have an awareness of them or know their selfconcept. Students must recognize personality traits that stand out in themselves, recognize their intellectual potential, know their cognitive strengths and weaknesses, recognize their skill areas, know the value of their life and understand what the difference between themselves and others is but still be able to accept these differences (Hamzah, Kai Le \& Musa, 2021; Lee Park \& Cho, 2020).

However, if students have high career self-efficacy, they will show better performance on having the higher desire to achieve something, having a little fear of failure and finding new strategies. Career selection is a process through which individuals identify and take steps to achieve their career goals (Akhsania, Basuki, Sugiharto \& Japar, 2020). Realistic career choices force individuals to see opportunities that are related to their abilities. In the stage of carreer selection, people are at the stage of exploration. The exploration stages include recognizing skills, obtaining relevant information for making career decisions, realizing interests and abilities and identifying the field and job that match to them (Wu et al., 2020). 
The concept of self-employment has become popular in various countries. In western countries, there are many of the college students who have self-employment career without considering their own abilities, interests and personalities. There is a tendency for individuals to follow the choices of their parents or friends, based on the popularity of their jobs or identification with their parents, so that people in their efforts to achieve the desired career choices often experience confusion. Individuals are said to be mature or willing to make career decisions if the knowledge they have to make career decisions is supported by strong information about the work based on the exploration that has been done (Chao, 2020; Super, 1990). The conceptual discussion of self-employment provides innovative solutions in solving social problems in the world of work such as reducing poverty and reducing unemployment issues which require synergy from all parties (Sejal, Robert, Stanley \& Jacob. 2020; Subhan et al., 2018).

To reduce the issue of poverty and unemployment requires careful career planning that includes self-knowledge, knowledge about job, the ability to choose the job, and the ability to plan steps towards the desired career. This is in line with the Presidential Regulation Number 142 of 2018 which states that students at universities must start thinking seriously about their future. So that they can choose the right career, about the career direction after graduating from college

From the various studies above, it can be seen that individual self-efficacy is closely related to the formation of self-employment careers. Thus, students who have high selfefficacy tend to make all efforts to gain achievement in academic, determine future steps with business and have a desire for self-employment. Looking at the phenomena in the field, it is not certain whether self-efficacy can affect to increase the choice of self-employment careers or not. This is because there is no definite measurement of the relationship between self-efficacy and career choices for these students.

\section{Research Background \\ Career Self-Efficacy (CSE)}

Self-efficacy can encourage individual's performance in various fields including selfemployment motivation (Kezar, Hypolite \& Kitchen, 2020). Therefore, in opening a business, self-confidence and self-efficacy are needed in order to make the business successful. The same thing was expressed by Bandura (1977) who defined self-efficacy as social cognitive theory or social reasoning, which refers to an individual's belief that he is capable of carrying out what he wants for the future.

According to Betz, Klein and Taylor (1996) defines that self-efficacy is a person's belief in his or her ability to perform tasks or actions needed to achieve certain results. Self-efficacy is a person's belief about his abilities to make the decisions he wants. Career is a job that is related to the process of life in the future. Every human being is a dynamic creature. It is always constantly changing, actively moving and always developing. A person will work happily, with great joy, if what is done is in accordance with his own desires, situation, condition, understanding and interests. To get all of those things, a career selection is needed.

According to Falco and Summers (2019), self-efficacy is an individual's assessment of his or her ability to organize and carry out a series of actions that are maximized to achieve what has been planned. Self-efficacy has an important role in influencing a person's effort, how strong the effort is and predicting the success that will be achieved. High self-efficacy tends to choose ways with bigger challenges. Great self-efficacy tends to require a lot of effort. Once 
the self-efficacy is on the high level, people will try harder to successfully complete their tasks and will last longer when faced with difficulties.

\section{Self-Employment Intention or Entrepreneurial Career}

Self-employment intention or entrepreneurial career refers to individual's tendency who to take risks to open a business on various occasions, possession of courage and independent mentality, without fear or anxiety even in uncertain conditions (Kisubi, Korir \& Bonuke, 2021). An entrepreneur, in his mind, always tries, looks for, takes advantage of, and creates business opportunities that can provide benefits. Those who become self-employment will recognize potential and learn to develop it to seize opportunities and organize businesses in realizing their dreams. According to Douglas and Shepherd (2002), individuals who have a selfemployment career will be able to be creative, innovative and strict to see opportunities and are always open to any positive input and positive changes that can bring the business to continue to grow and have value. One of the drivers of innovation besides change and the need to adapt is awareness of the chance in what the community wants and what the government has offered or done (Mohammed, Baffour \& Rahaman, 2021).

According to Davidson (1995) the term self-employment intention is better known as entrepreneur, both of which have the same meaning. So an entrepreneur is a person who has the character of courage to take risks, virtue and exemplary in handling business based on his own ability and will. The concept of human development views maturity and independence in career decision making with courage (Ajzen, 1991; Super, 1990).

An entrepreneurial spirit refers to a person who is confident, optimistic, and full of commitment, takes initiative, has achievement motives, has a leadership spirit and is brave to take risks (Darmayanti, Prasetyo, Winata \& Sakti, 2020). According to (Krueger \& Carsrud, 1993), the concept of self-employment intention or entrepreneurship refers to the belief in one's own abilities, in every action it is always task and result-oriented, always has the courage to take risks, has a leadership spirit in every activity, has a commitment to originality and has foresight. Individuals who like self-employment have the ability to create something different from the others and are able to think creatively and act innovatively in order to create opportunities in the business world. Self-employment have dominant characteristics where they have a big confidential and always think that they have better abilities than coworkers. self-employment need freedom. People who have a self-employment spirit break the existing economic system by introducing new goods and services by creating new forms or processing new raw materials. Thus, the selection of a self-employment career is very suitable for students who are about to graduate from college to provide employment opportunities for others. Therefore, someone needs career self-efficacy for an entrepreneurial career choice (Yadav, 2020; Tiwari, Patro \& Patky, 2020).

\section{Methodology}

The purpose of this study is to see the effect of career self-efficacy on self-employment career choices among state university students in Riau. This is a quantitative research that explains the results in the form of numbers which are interpreted with maximum results (Tashakkori, Johnson \& Teddlie, 2020; Creswell \& Creswell, 2017). The population of this research is students of state universities in Riau. The sample of this study was 778 state university students in Riau. The sample of this research is final year college students who are ready to choose a career. The sampling technique uses random sampling techniques. 
The main instrument used is the Career Decision Making Self-Efficacy (CDMSE) consisting of 25 items and the self-employment intention instrument consisting of 11 items with a Likert scale. The instrument is developed by Betz, Klein and Taylor (1996) has the Cronbach Alpha value of 0.90 which shows a high consistency value. In addition, the SelfEmployment Intention developed by Krueger and Carsrud (1993) that has the Cronbach Alpha value of 0.83 was used as secondary instrument. The data analysis of this study was conducted using Statistical Package for Social Sciences (SPSS) software, version 24.in terms of descriptive and inferential analysis.

\section{Results}

The results of this study are seen from the demographic descriptive statistics which can be shown in the following table.

Table 1: Demographic characteristic of the participants

\begin{tabular}{lcc}
\hline Demographic characteristics & F & (\%) \\
\hline Man & 416 & $53.5 \%$ \\
Women & 362 & $46.5 \%$ \\
Total & 778 & $100 \%$ \\
High Socio Economic Status (Exceeding IDR 4,400,000) & 232 & $29.9 \%$ \\
Medium Socio Economic Status (IDR 2,200,000-IDR & 294 & $37.7 \%$ \\
4,400,000) & & \\
Low Socio-Economic Status (Less than Rp. 2,200,000) & 252 & $32.4 \%$ \\
Total & 778 & $100 \%$ \\
\hline
\end{tabular}

Table 1 shows 416 men (53.5\%) and 362 women (46.5\%). In addition, the high socioeconomic status of 232 students (29.9\%), middle socioeconomic status of 294 students (37.7\%) and low socioeconomic status of 252 students (32.4\%).

Descriptive statistics on the measures of career self-efficacy and self-employment career Based on the results of descriptive research to see career self-efficacy and self-employment career choices can be seen in the table below.

Table 2: Mean and standard deviations of career self-efficacy and self-employment career

\begin{tabular}{ccccccc}
\hline Variable & N & M & SD & Minimum & $\begin{array}{c}\text { Maximu } \\
\mathbf{m}\end{array}$ & Category \\
\hline Career Self-Efficacy & 778 & 3.72 & .652 & 1.52 & 4.76 & High \\
$\begin{array}{c}\text { Self-Employment } \\
\text { Career }\end{array}$ & 778 & 3.81 & .638 & 2.18 & 4.91 & High \\
\hline
\end{tabular}

Table 2 shows that the descriptive results of career self-efficacy are at a high stage, which can be seen from the mean and standard deviation, namely $(M=3.72, S D=.652)$. Then, the descriptive results of Self-Employment Career are at a high stage. This descriptive result was found from the mean and standard deviation, namely $(M=3.81, S D=.638)$. 


\section{Correlational analysis results of the relationship between career self-efficacy and self- employment career}

Table 3: Relationship between career self-efficacy and self-employment career

\begin{tabular}{ccc}
\hline Variable & Career Self-Efficacy & $\mathbf{N}$ \\
\hline Self-Employment Career & .53 & 778 \\
\hline
\end{tabular}

This study uses Pearson correlation analysis to see the relationship between career selfefficacy and self-employment career, which indicates a strong relationship expectation by the results $(r=.53 ; p<.05)$. There is a positive relationship between career self-efficacy and selfemployment career.

\section{Regression analysis results of the predictor value of career self-efficacy for self-employment career}

Table 4: Linear regression analysis of career self-efficacy for self-employment career

\begin{tabular}{cccccccc}
\hline Variable & $\boldsymbol{B}$ & $\boldsymbol{S E}$ & Beta & $\boldsymbol{T}$ & $\boldsymbol{p}$ & Pair & Partial \\
\hline Constant & 2,499 & .105 & & 23,733 & .000 & & \\
CSE & .406 & .032 & .525 & 12,688 & .000 & .525 & .525 \\
$\mathrm{R}=.525$ & $\mathrm{R} 2=.414$ & & & & & & \\
\hline
\end{tabular}

Note. $p<.05$.

Regression analysis is used to see the effect between two variables to predict well. In this study, simple linear regression looks at how career self-efficacy level affects selfemployment career. Table 4 shows that there is a significant influence between career selfefficacy level on self-employment career of state university students in Riau $(R=.525, R 2=$ $.414, \mathrm{p}<.05)$.

The presentation of this data is based on research carried out at state universities in Riau which was found to have a significant effect, namely $\mathrm{R} 2=.414$ which is the percentage of $41.4 \%$. The $58.6 \%$ is influenced by other factors.

\section{Discussion}

After the data analysis has been explained, the data collected by questionnaire and documentation were analyzed using quantitative methods and statistical analysis using the SPSS version 24 application. Based on the results of the research questionnaire, the data on career self-efficacy and self-employment career of the students are in the high category.

In a study conducted by Wu, Zhang, Zhou and Chen (2020), it is found that career selection is necessary for each individual. The higher the individual has career self-efficacy, the higher the self-employment career will be. Even though individuals have failed in selfemployment, with the presence of career decision making self-efficacy for doing business, individuals are more serious about continuing the business they are interested in.

The results of previous studies explained that college students have a high selfemployment career. High self-employment career is influenced by the efficacy of career independence of students who have a high confidence. The characteristic of individuals who have career decision making self-efficacy is knowing one's own abilities, having effort in career selection, having confidence, believing in itself, having career selection efforts, having career dreams/career goals, making future career plans, having career problem solving, 
Maintaining the chosen career \& having seriousness / consistency in choosing a career (Hamzah, Kai Le \& Musa, 2021; Darmayanti, Prasetyo, Winata \& Sakti, 2020).

Moreover, the stage of studets' self-efficacy to self-employment is very necessary to ensure the ability to choose a career in the future. The change in the efficacy of career is closely related to the perception of the individual. To determine whether their perceptions are positive or not is dependent on the values and beliefs held by an individual. This means that if they have career independence efficacy or belief in something that is positive, then the tendency to become self-employed will also be positive. It will influence individuals to become self-employed to be positive after completing the college.

In addition, the results of regression analysis research which found the influence of the students' self-efficacy on the choice of self-employment careers among state university students in Riau. Students need confidence and determination in making career decisions, so that there is no hesitation in making career decisions. In fact, it is a responsibility of the counselor to seriously carry out career guidance and counseling program activities at the university. So, high individual self-efficacy can contribute to student career choices at university.

Supported by Falco and Summers (2019) which explain that students who have high career decision making self-efficacy in career choices will have an influence on the tendency to become self-employed. This is caused by his own efforts to achieve something he wants. The higher the individual's efforts to achieve a self-employment career, the higher the tendency to become self-employed. Therefore, individuals need to have high effort to choose the career they want. Commitment in choosing work shows that students are serious and consistent in the chosen self-employment career, which can affect the tendency to become self-employed employed (Ann Marie, 2021; Lee, Park \& Cho, 2020; Gori et al., 2020).

Previous research by Mahmud et al. (2019) examined the analysis of student selfefficacy at universities. Based on the results of this research, it concluded that self-efficacy is very necessary, because later it will prepare students who can immediately work when they graduate. The research with the subject of undergraduate students found several factors that influence self-efficacy like self-knowing, understanding the world of work, choosing the job, making future work plans and making problem solving about work which is very influential on career choices. There are many experts who support the formation of self-efficacy because it will help to have a good self-employment career choice if from the internal (mindset, insight) and external (environmental) perspectives of them are well supported.

In addition, this research has implications for career programs in improving the selfefficacy needed to be carried out by universities. The program may be implemented in classical, group, individual and special formats. In general, career programs at universities use more learning activities and extra programs in providing career guidance and counseling such as the formation of career decision making self-efficacy for the formation of self-employment career choices with a competency program pattern (Mahmud \& Amat, 2018).

After the career program is implemented, the career program manager immediately follows up on whether the services they have provided are effective, such as asking if there has been a change. If there is no change, they will provide more services until there is an expected change in the student. In addition, strategies are also given so that students have a self-employed desire such as providing information about careers, providing tips on being independent to do business, providing career guidance and counseling services. So the implementation program of giving career decision making self-efficacy is very influential in the career selection process, especially in the selection of a self-employment career. 
Self-employment programs are important to be implemented in universities which must be excellent programs so that it is easy for students to be creative and innovative in solving problems and clever in taking advantage of the opportunities that exist around the university (D'Souza, 2020; Sejal, Robert, Stanley \& Jacob, 2020). Self-employment career arises when someone has an interest in self-employment, which is a dynamic process of creating goods and services and products that are new and different from others. The ability to create something new and different through creative thinking and innovative actions for the creation of a self-employment mindset is critical nowadays (Matijas \& Sersic, 2021; Liu, Lin, Guanxi \& Dali, 2019; Atitsogbe et al., 2019).

Some of the capitals to form self-employment career include financial capital, courage capital, self-efficacy capital, confidence capital, creative capital, intellectual capital, social capital, trust capital, mental capital and social innovation. Some capital is a combination to form self-employment career that allows individuals to improvise a product to create a business. The self-employment mentality must be planted early, because mental capital readiness starts from an early age and then is manifested in the form of courage to face risks and challenges. Students must be able to learn to manage risk by transferring various risks to other parties such as banks, investors, consumers, suppliers and novelty innovations and improvements. Novelty innovation here does not have to be in the form of creating a new product but it can also be on the side of the product's benefits for many people. Likewise, improvement innovation is the provision of the best alternative innovations that are the most efficient and effective for a process or a product. Something that is innovated requires consideration for the product creation process, then there is also the need to consider the existence of innovations that can be spread and innovations that are adopted from other people's products (Ahn \& Yu, 2020; Faria, Cuestas, Gil-Alana \& Mourelle, 2020; Dinh et al., 2020).

Moreover, activities and innovations designed by individuals to create a product that can be liked by many people to be sold and bought. If the students have reached the stage of social innovation and creative thinking at the university, it will be easy for the process of choosing a self-employment career.

\section{Conclusion and Recommendations}

Based on the results of the research, it can be concluded that career self-efficacy on selfemployment career is in a high stage so that it gives inspiration and motivation to selfemployment. Career selection activities in enhancing self-employment career choices tend to operate with the aim of creating value for society as well as generating income. Selfemployment career is very beneficial for the poor, in general and for the younger generation who are going to get involved in work.

Individuals need to have career self-efficacy to instill in individuals for self-employment career. Moreover, being a self-employed does not really need lot of capitals; especially in every country there must be a program that helps people to be given self-employment capital which is a joint program between the government and the community. Marketing and promotion for doing business will easily be caused by using social media and mobile phones.

In determining superior and innovative human resources, universities should make more programs to create career self-efficacy and self-employment career that will prosper university alumni to become bright and successful. This is because students who choose selfemployment can give many benefits for others. Especially to reduce unemployment that will create job opportunities and support the country's economy towards better direction. 
It is a must to have a mature strategy before plunging into self-employment. Primarily is having career self-efficacy so that it is easy to choose a self-employment career after graduating from university. The use of social media and technology needs to be utilized for future interests, especially to support starting a business. For this reason, having a small businesses during the college will provide experience to self-employment career choices, so it is very necessary to take part in career programs made by universities for students to build a successful business spirit after graduating from university.

Suggestions given to students should always have an effort to improve competencies especially on career decision making self-efficacy in order to improve students' selfemployment that are truly skilled and innovative. The education at the university should pay more attention to the needs of the students. The university guides and provides direction to students with the aim of more effective and efficient learning activities to design their future during college. In addition, it is also hoped that students can realize that self-employment is a business opportunity that is able to open jobs for themselves and others.

In addition, this research needs to select research subjects with different characteristics. Likewise, it is necessary to add and expand variables so that it can see many other factors that influence the choice of a self-employment career. This is very important to provide complete, in-depth and tested scientific information which will ultimately be able to contribute in advancing the interests of the academic field and bright young generations.

\section{Acknowledgement}

The authors are grateful to the Faculty of Education, UKM for assistance in improving the manuscript via professional services with the utilization of research funding (Code: GG-2019028).

\section{References}

Abdelkarim, A. (2021). From entrepreneurial desirability to entrepreneurial self-efficacy: the need for entrepreneurship education-a survey of university students in eight countries. Entrepreneurship Education, 4, 67-88.

Ahn, T. S., \& Yu, Y. J. (2020). Effects of career guidance courses on self-efficacy in career path decisions and career maturity of university students. Journal of Convergence for Information Technology, 10(10), 174-182.

Akhsania, K., Basuki, T., Sugiharto, D., \& Japar, M. (2020.) Students' career understanding and career decision making self-efficacy in junior high school. Islamic Guidance and Counseling Journal, 4(1), 12-20.

Ajzen I. (1991). Theory of Planned Behaviour. Organization Behaviour and Human Decision Processes, 2, 179-221.

Marie, A. B. (2021). Constructing a graduate career future: Working with Bourdieu to understand transitions from university to employment for students from working-class backgrounds in England. European Journal of Education. 56(1), 78-92.

Atitsogbe, K. A., Mama, N. P., Sovet, L., Pari, P., \& Rossier, J. (2019). Perceived employability and entrepreneurial intentions across university students and job seekers in Togo: The effect of career adaptability and self-efficacy. Frontiers in Psychology, 10, 180.

Bandura, A. (1977). Social Learning Theory. New York, NY: General Learning Press.

Betz, N. E., Klein, K. L., \& Taylor, K. M. (1996). Evaluation of a short form of the Career Decision-Making Self-Efficacy Scale. Journal of Career Assessment, 4, 47-57. 
Chao, S. Y. (2020). The Relationship among Self-Identity, Perceived Career Barriers, Social Support, Career Decision Self-Efficacy and Outcome Expectations of College Students with Disabilities. PhD. Dissertation, Southern Illinois University at Carbondale.

Creswell, J. W., \& Creswell, J. D. (2017). Research Design: Qualitative, Quantitative, and Mixed method Approaches (5 $5^{\text {th }}$ ed.). Thousand Oaks, CA: SAGE Publications.

Darmayanti, K. K. H., Prasetyo, D. T., Winata, E. Y., \& Sakti, P. (2020). What will you do after graduated from university? Increasing career decision self-efficacy through career counseling. Jurnal Kesejahteraan Keluarga dan Pendidikan (JKKP), 7(1), 26-37.

Davidson, P. (1995). Determinants of Entrepreneurial Careers. Paper presented at the RENT IX Conference, Workshop in Entrepreneurship Research, Piacenza, Italy. 23-24 November.

Dinh, H., Martin, A., Leach, L., Strazdins, L., Nicholson, J., Allen, T., \& Cooklin, A. (2020). Is selfemployment a good option? Gender, parents and the work-family interface. Sex Roles, 79(8). 1-16.

D'Souza, E. (2020). Self-Employment and Human Capital. Springer Briefs in Economics, in: Conceptualizing the Ubiquity of Informal Economy Work, 13-18.

Falco, L. D., \& Summers, J. J. (2019). Improving career decision self-efficacy and STEM selfefficacy in high school girls: Evaluation of an intervention. Journal of Career Development, 46(1), 62-76.

Faria, J. R., Cuestas, J. C., Gil-Alana, L. \& Mourelle, E. (2020). Self-Employment by Gender in the EU: Convergence and Clusters. Working Papers 2020/22, Economics Department, Universitat Jaume I, Castellón (Spain).

Gori, A., Palazzeschi, L., Gazzaniga, M., Topino, E., \& Di Fabio, A. (2020). The relationship between intrapreneurial resources and decision-making self-efficacy in university students. Counseling, 13(2), 83-93.

Griffin, K. M. (2020). Exploring the Relationship Between Attachment Styles And Career Decision-making Self-efficacy Among African Americans. PhD. Dissertation, Mercer University.

Hamzah, S. R. A., Kai Le, K., \& Musa, S. N. S. (2021). The mediating role of career decision selfefficacy on the relationship of career emotional intelligence and self-esteem with career adaptability among university students. International Journal of Adolescence and Youth, 26(1), 83-93.

Kezar, A., Hypolite, L., \& Kitchen, J. A. (2020). Career self-efficacy: A mixed-method study of an underexplored research area for first-generation, low-income, and underrepresented college students in a comprehensive college transition program. American Behavioral Scientist, 64(3), 298-324.

Kisubi, M., Korir, M., \& Bonuke, R. (2021). Entrepreneurial education and self-employment: Does entrepreneurial self-efficacy matter? SEISENSE Business Review, 1(1), 18-30.

Krueger, N. F., \& Carsrud, A. L. (1993). Entrepreneurial careers: Applying the theory of planned behavior. Entrepreneurship and Regional Development, 5, 315-330.

Lee, H. J., Park, J. Y., \& Cho, K. D. (2020). Effects of parental attachment on career maturity in university students: Moderating effect of career decision-making self-efficacy and cognitive flexibility. The Journal of the Korea Contents Association, 20(3), 324-335.

Liu, X., Lin, C., Guanxi, Z., \& Dali, Z. (2019). Research on the effects of entrepreneurial education and entrepreneurial self-efficacy on college students' entrepreneurial intention. Frontiers in Psychology, 10, 869. 
Mahmud, M. I., Noah, S. M., Jaafar, W. M. W., Bakar, A. Y. A., \& Amat, S. (2019). The career readiness construct between dysfunctional career thinking and career self-efficacy among undergraduate students. Journal of Engineering Science and Technology, Special Issue (June), 74-81.

Mahmud, Z., \& Amat, S. (2018). Kemahiran Kaunseling: Sebagai Strategi Membantu. Bangi, Selangor: UKM Press.

Matijas, M., \& Sersic, D. M. (2021). The relationship between career adaptability and jobsearch self-efficacy of graduates: The bifactor approach. Journal of Career Assessment. https://doi.org/10.1177/10690727211002281

Mohammed, I., Baffour, P. T., \& Rahaman, W. A. (2021). Gender differences in earnings rewards to personality traits in wage-employment and self-employment labour markets. Management and Labour Studies. https://doi.org/10.1177/0258042X21989944

Pambudi, A. T., Mulawarman, M., \& Japar, M. (2018). Psychoeducational group with modelling technique to improve career adaptability through career decision selfefficacy. Jurnal Bimbingan Konseling, 8(1), 20-31.

Saks, A. M. (2006). Multiple predictors and criteria of job search success. Journal of Vocational Behavior, 68, 400-415.

Subhan, M., Zein, M., Akhyar, Abidin, M. H. Z., Ali, S., Amat, S., Mahmud, M. I., Hamid, A. H. A., \& Bakar, A. Y. A. (2018). Reliability of self-employment careers instrument among international students in Indonesian university. International Journal of Engineering \& Technology UAE. 7(2.10), 76-79.

Super, D. E. (1990). A life-span, life-approach to career development. In D. Brown \& L. Brooks (Eds.), Career choice and development: Applying contemporary approach to practice (pp. 197-261). San Francisco, Jossey-Bass.

Sejal, P. F., Robert, M., Stanley, B. B., \& Jacob, O. (2020). Self-efficacy for enhancing students' career and college readiness: A survey of professional school counselors. Journal of Counseling \& Development, 98(2), 183-192.

Tashakkori, A. M., Johnson, B. R., \& Teddlie, C. B. (2020). Foundations of Mixed Methods Research ( $2^{\text {nd }}$ ed.). Thousand Oaks, CA: SAGE Publications.

Tiwari, A., Patro, A., \& Patky, J. (2020). Information communication technology and selfemployment. In Sikdar S., Das R. C., Bhattacharyya R. (Eds.), Role of IT- ITES in Economic Development of Asia (pp. 235-249). Springer, Singapore.

Wu, S., Zhang, K., Zhou, S., \& Chen, W. (2020). Personality and career decision-making selfefficacy of students from poor rural areas in China. Social Behavior and Personality, 48(5), 1-18.

Yadav, A. (2020). Investigating the role of self-ffficacy in shaping academic and career trajectories of management students. International Journal of Management (IJM), 11(10), 226-236. 